\title{
Nitrogen and phosphorus phytoplankton growth limitation in the northern Gulf of Mexico
}

\author{
R. Eugene Turner ${ }^{1, *}$, Nancy N. Rabalais ${ }^{2}$ \\ ${ }^{1}$ Coastal Ecology Institute and Department of Oceanography and Coastal Sciences, Louisiana State University, Baton Rouge, \\ Louisiana 70803, USA \\ ${ }^{2}$ Louisiana Universities Marine Consortium, 8124 Highway 56, Chauvin, Louisiana 70344, USA
}

\begin{abstract}
We conducted 158 bioassays to determine phytoplankton growth limitation in the northern Gulf of Mexico and made the following observations. Light limitation occurred where salinity was $<20$; at higher salinities, phytoplankton biomass yield became mostly limited by $\mathrm{N}$ or by a co-limitation of $\mathrm{N}$ plus $\mathrm{P}$ (NP). The number of N-limited bioassays was 5 times greater than the P-limited bioassays. NP synergism occurred where salinity was $>20$, and represented $59 \%$ of all samples that were not light-limited. The interaction of $\mathrm{N}$ and $\mathrm{P}$ co-limitation was frequently synergistically additive, i.e. the combined effects of $\mathrm{N}$ and $\mathrm{P}$ limitation together created a greater response than the sum of either separately. The dissolved inorganic nitrogen:phosphate ratio (DIN:Pi) and various concentrations of DIN and Pi did not offer reliable chemical boundaries describing likely areas of exclusive $\mathrm{N}$ or $\mathrm{P}$ limitation in these bioassays. We conclude that reducing $\mathrm{N}$ loading to the shelf is a prudent management action that will partially remediate eutrophic conditions, including those that lead to hypoxia, but the omission of a concurrent reduction in $\mathrm{P}$ loading would be shortsighted.
\end{abstract}

KEY WORDS: Nutrient limitation - Algal community $\cdot$ Eutrophication $\cdot$ Hypoxia $\cdot$ N:P ratios Mississippi River

Resale or republication not permitted without written consent of the publisher

\section{INTRODUCTION}

Nitrogen loading (primarily nitrate-N) from the Mississippi River (USA) watershed to the continental shelf within the last few decades is positively related to chlorophyll a ( $\mathrm{chl}$ a) concentration (Walker \& Rabalais $2006 ; R^{2}=0.30$ to 0.42 ), the rate of primary production (Lohrenz et al. 1997, 2008; $\mathrm{R}^{2}>0.77$ ), and the spatial extent of the hypoxic area in summer (Turner et al. 2012; $R^{2}>0.9$ ). The size of the shelfwide hypoxic zone has increased since it began occurring in the 1970s, simultaneously with the rise in carbon sequestration in sediments, indicators of increased diatom production, and shifts in foraminiferal communities (Turner \& Rabalais 1994, Sen Gupta et al. 1996, Turner et al. 2008). There is, therefore, a series of cause-and-effect arguments linking $\mathrm{N}$ loading in the river to phytoplankton production, to bottom water oxygen demand, and to the formation and maintenance of the largest hypoxic zone in the western Atlantic Ocean.

While an ecosystem response to nutrient loading has been demonstrated, the relationship between phytoplankton production rates and both nutrient concentration and their ratios is less clear. The nutrient concentration determines part of the exchange rate between the cell and its medium, and changes with uptake, transformations, and losses that vary along the mixing gradient from river to sea. Both $\mathrm{N}$ and phosphorus $(\mathrm{P})$ are essential nutrients, and quantifying their significance to phytoplankton growth informs decisions about whether $\mathrm{N}, \mathrm{P}$, or both should be managed. A complicating factor is that nutrient loading into the area is not constant. Riverine $\mathrm{N}$ load- 
ing, for example, has increased many times since the early 1900s, but we know less about changes in $\mathrm{P}$ loading (Turner et al. 2007, Broussard \& Turner 2009). The N:P molar ratio of various forms of $N$ and $\mathrm{P}$ in the river has changed seasonally and annually since the 1950s when systematic water quality sampling of the Mississippi River at St. Franscisville, Louisiana, by the US Geological Survey (USGS) began (http://toxics.usgs.gov/hypoxia/mississippi/flux_ests/ delivery/index.html). The average annual ratio of total N:total P rose from less than 10:1 in the late 1970s to around 40:1 within a decade, and then declined to half that value by the 1990s (Turner et al. 2007). These values fluctuate over decades above and below the Redfield ratio of 16:1::N:P.

Two notable problems encountered when using nutrient concentrations or their ratios to imply nutrient limitation of phytoplankton growth are that (1) many phytoplankton have such a high affinity for $\mathrm{N}$ and $\mathrm{P}$ that, if limiting, the amounts of $\mathrm{N}$ or $\mathrm{P}$ may be below detection by the usual analytical techniques, and (2) phytoplankton may modulate 'both their internal nutrient quota and their maximum short term uptake rates in response to variations in external nutrient concentrations' (Morel 1987, p. 137). The uptake efficiency can change with cell nutritional status or concentration, and the nutrient concentration can also be affected by the loss of nutrients from the cell because of changes with death and excretion - both of which can be independent of gross uptake. Both uptake and mineralization influence concentration so that concentration, and the ratio of concentrations, can vary non-linearly for systems that are not in an equilibrium state, e.g. a river plume. As a result, a phytoplankton community could have twice the standing stock of chl a compared to another community, but the concentration of nitrate could be half as much, or vice versa. The standing stock of nutrients therefore cannot be taken as a reliable indicator of nutrient status. Dodds (2006, p. 214) briefly reviewed the relevant literature and concluded: 'standing stocks of dissolved inorganic nutrient concentrations give ambiguous information about nutrient limitation and availability.'

Two other approaches to determine nutrient limitation of algal growth are bioassays and physiological (cellular) assays. There are both advantages and disadvantages to using each approach. Physiological assays may be time-consuming and insufficient by themselves, whereas chemical determinations can be relatively simple to use, and, therefore, used frequently. A suite of different assays is sometimes used because of these issues.
Nutrient bioassay experiments are used to understand what nutrients limit phytoplankton growth and to explore the relationship(s) between nutrient limitation and nutrient stoichiometry. A bioassay is usually a simple cultivation of natural or cultured algal assemblages under various controlled conditions and whose volumetric scale may range from $<1 \mathrm{ml}$ to $10^{3} \mathrm{~m}^{3}$ (e.g. Nixon et al. 1984, Blaise et al. 1986). Bioassays may be conducted to measure growth rate or growth yield as influenced by nutritional factors and inhibitory substances. Bioassays are experimental and can be easy to use. The criteria for what is 'limiting' or not, however, can be subjective, and few studies have quantified the standards (sensu Fisher et al. 1999).

Three sets of investigators used bioassays to determine the growth-limiting nutrient on the Mississippi River-influenced continental shelf where seasonal hypoxia is an annual event (Smith \& Hitchcock 1994, Sylvan et al. 2006, Quigg et al. 2011). Their samples were taken between the Mississippi and Atchafalaya rivers from 1991 to 2004. This set of 30 observations included conclusions about $\mathrm{N}, \mathrm{P}, \mathrm{N}$ plus $\mathrm{P}(\mathrm{NP})$, and light limitation, and each used observations about dissolved inorganic nitrogen (DIN) and phosphate (Pi) concentrations and nutrient ratios to supplement their interpretations. Here, we describe a larger set of observations extending farther across the shelf, for many more months and years, and for the complete salinity range from the river to the seawater mixing end member. We used these data to quantify the range at which light limitation occurs, the frequency of $\mathrm{P}, \mathrm{N}$, and NP limitation, and the synergism of $\mathrm{N}$ and $\mathrm{P}$ on phytoplankton growth. We asked the fundamental question: What is the relative influence of $\mathrm{N}$ and $\mathrm{P}$ on phytoplankton growth limitation in a eutrophied coastal ocean? We also used these data and the published results to address the issue of how well the N:P ratios can be used to circumscribe a chemically-defined space where $\mathrm{N}, \mathrm{P}$, or NP limitation occurs. The results are of relevance to discussions of reducing nutrient loading as a means to reduce the size of the hypoxic zone.

\section{MATERIALS AND METHODS}

We used freshly collected natural phytoplankton communities to conduct bioassay experiments using nitrate and phosphate as separate additions and in combination with each other. Addition experiments have been in use since at least 1910 (Allen \& Nelson 1910), and have been the preferred method for many 
estuarine studies on algal nutrient limitation for decades (e.g. D'Elia et al. 1986, Caraco et al. 1987). A positive growth or biomass accumulation (above that in the control) following the addition of nutrients may be interpreted as evidence of nutrient limitation in the original sample. Lack of net biomass accumulation with 1 nutrient added does not, however, mean that this nutrient is not limiting, because that nutrient may be limiting in combination with other nutrients. Enhanced algal growth or biomass accumulation supports the hypothesis of nutrient limitation for that treatment, assuming that no inhibitory effects occur. The observed changes in net biomass in the experiments are used to infer nutrient limitation on phytoplankton growth.

\section{Sample collection}

The 158 bioassay experiments described below used samples collected from the upper $1 \mathrm{~m}$ of Louisiana continental shelf water using a nearsurface Niskin bottle or bucket from April to November (Fig. 1). Eighty-one bioassays were completed between 1981 and before 2010, 62 in 2010, and 15 in 2011. These samples were collected in 8 different months and in 10 different years. No bioassays were conducted in January, February, March, or December.

The spatial distribution of the sample locations is shown in Fig. 2, along with the 14 bioassays reported in the literature that we analyzed. Samples were taken in 2010 from the $\mathrm{C}$ and $\mathrm{F}$ transects (Fig. 2), which are oriented northwest-to-southeast, and north-to-south, respectively, with the innermost station at about 90.5 and $91.7^{\circ} \mathrm{W}$, respectively. The C

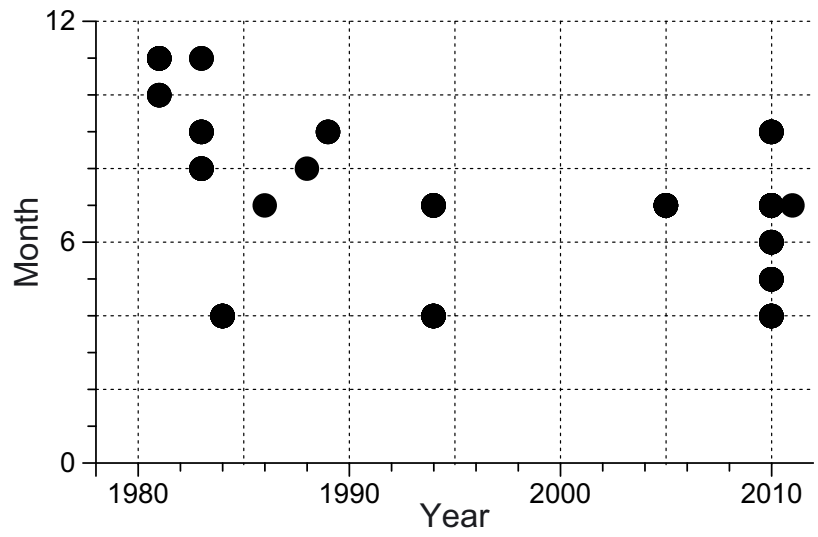

Fig. 1. Temporal distribution of the 158 bioassay experiments. Of the bioassays, 81 were conducted before 2010, 62 in 2010, and 15 in 2011. Each data point represents multiple bioassays and $\mathrm{F}$ transects are about 80 to $250 \mathrm{~km}$, respectively, west of the mouth of the Mississippi River, and the F transect is offshore of the Atchafalaya River delta. Samples were collected on the annual summer hypoxia cruise in late July in 1984, 1994, 2005, 2010, and 2011.
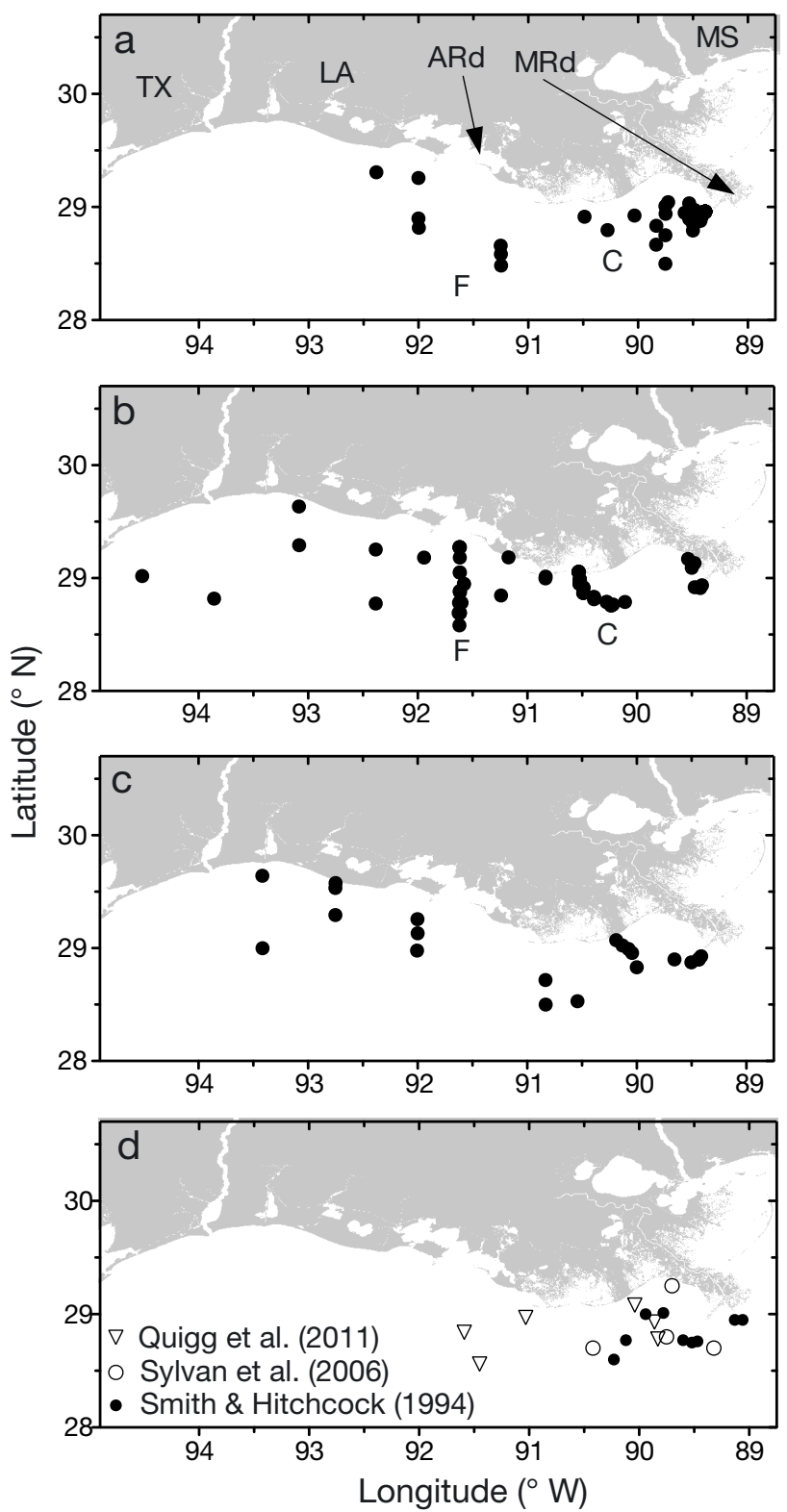

Fig. 2. Spatial distribution of the bioassay experiments conducted in this study and the literature. (a) Sampling stations ( $\mathrm{n}=81$ bioassays) before 2010. ARd and MRd are the Atchafalaya and Mississippi River deltas, respectively. (b) Sampling stations ( $\mathrm{n}=62$ bioassays) in 2010. The $\mathrm{C}$ and $\mathrm{F}$ transects are labeled. (c) Sampling stations ( $\mathrm{n}=15$ bioassays) in 2011. (d) Sampling stations ( $\mathrm{n}=14$ bioassays) for results described in the literature. TX: Texas, LA: Louisiana, MS: Mississippi 


\section{Experimental protocol}

Zooplankton were screened (200 $\mu \mathrm{m}$ nitex filter) from samples to minimize the confounding effects of zooplankton grazing. The change in phytoplankton biomass in a $10 \mathrm{ml}$ test tube culture was estimated daily as relative fluorescence using a Turner fluorometer equipped with a Corning CS.5-60 filter, an F4T4-BL excitation lamp, and a Corning CS.264 filter for the emitted light. The growth in the bioassay experiments was evaluated on the basis of net growth in a tube with the nutrient additions compared to net growth in an untreated 'control' tube. Experiments normally extended 2 to $3 \mathrm{~d}$ past the peak biomass accumulation for a total of 5 to 10 d. Samples for shipboard experiments were incubated in flowing water and without screens at in situ temperatures on the most illuminated and accessible part of the ship. Samples whose growth lasted longer than the cruise were transferred to a laboratory incubator with light $(14: 10 \mathrm{~h}$ on:off; $220 \mu \mathrm{E}$ ) and incubated within $2^{\circ} \mathrm{C}$ of the in situ temperature.

A total of 143 experiments were completed using the following nutrient additions: inorganic $\mathrm{N}$ (as $\left.\mathrm{NaNO}_{3}\right)$, inorganic $\mathrm{P}\left(\mathrm{Pi}\right.$, as $\left.\mathrm{NaH}_{2} \mathrm{PO}_{4}\right)$, and $\mathrm{N}$ and $\mathrm{Pi}$ combined. The amount of nitrate- $\mathrm{N}$ and $\mathrm{Pi}$ added was sufficient to raise the nutrients in the test tube to at least $30 \mu \mathrm{M}$ nitrate and $2 \mu \mathrm{M}$ Pi.

Fifteen additional samples collected in July 2011 were used to determine the relative response to only $\mathrm{Pi}$ additions as described above, and to $1 \mathrm{ml}$ of filtered (0.45 $\mathrm{mm}$ cellulose ester filters, Millipore) Mississippi River water collected on the first day of the cruise. The Pi additions were added separately, and together with the river water.
Table 1. Generic examples of how nutrient limitation was determined using relative fluorescence units. See 'Materials and methods' for more details. Note: the 'Light'-limited bioassay result has no nutrient additions. NP: N plus P

\begin{tabular}{|c|c|c|c|c|}
\hline & Start & End & $\begin{array}{l}\% \text { change } \\
\text { of maximum }\end{array}$ & Interpretation \\
\hline \multicolumn{5}{|c|}{ Example 1: Maximum change $=50(100-50)$} \\
\hline Light & 50 & 50 & 0 & $<50 \%$; no light limitation \\
\hline$+\mathrm{N}$ & 50 & 100 & 100 & $>75 \% ; \mathrm{N}$ limitation \\
\hline$+\mathrm{P}$ & 50 & 55 & 10 & No P limitation \\
\hline$+\mathrm{NP}$ & 50 & 90 & 80 & $\begin{array}{l}\text { No NP limitation, because } \\
\mathrm{N} \text { alone results in a similar } \\
\text { net change that is }>75 \%\end{array}$ \\
\hline \multicolumn{5}{|c|}{ Example 2: Maximum change $=40(90-50)$} \\
\hline Light & 50 & 60 & 25 & $<50 \%$; no light limitation \\
\hline$+\mathrm{N}$ & 50 & 90 & 100 & $>75 \% ; N$ limitation \\
\hline$+\mathrm{P}$ & 50 & 90 & 100 & $>75 \%$; P limitation \\
\hline$+\mathrm{NP}$ & 50 & 90 & 100 & $\begin{array}{l}>75 \% \text {, but } \mathrm{N} \text { or } \mathrm{P} \text { alone } \\
\text { results in a similar net } \\
\text { change; no NP synergism }\end{array}$ \\
\hline \multicolumn{5}{|c|}{ Example 3: Maximum change $=50(100-50)$} \\
\hline Light & 50 & 50 & 0 & $<50 \%$; no light limitation \\
\hline$+\mathrm{N}$ & 50 & 60 & 20 & $<75 \%$; no N limitation \\
\hline$+\mathrm{P}$ & 50 & 70 & 40 & $<75 \%$; no P limitation \\
\hline$+\mathrm{NP}$ & 50 & 100 & 100 & $\begin{array}{l}>75 \% \text { and } \mathrm{N} \text { and } \mathrm{P} \text { addition } \\
\text { are }<75 \% ; \mathrm{NP} \text { limitation }\end{array}$ \\
\hline \multicolumn{5}{|c|}{ Example 4: Maximum change $=50(100-50)$} \\
\hline Light & 50 & 90 & 80 & $>50 \%$; light limitation \\
\hline$+\mathrm{N}$ & 50 & 80 & 60 & $\begin{array}{l}<75 \% \text {; light results in a } \\
>50 \% \text { change } \\
\text { no } N \text { limitation }\end{array}$ \\
\hline$+\mathrm{P}$ & 50 & 100 & 100 & $\begin{array}{l}>75 \% \text {, but light alone } \\
\text { results in a }>50 \% \text { net } \\
\text { change; no P limitation }\end{array}$ \\
\hline$+\mathrm{NP}$ & 50 & 90 & 80 & $\begin{array}{l}>75 \% \text {; light alone results } \\
\text { in a }>50 \% \text { net change; } \\
\text { no NP limitation }\end{array}$ \\
\hline
\end{tabular}

\section{Determination of nutrient responses}

Our definitive test used to decide which nutrient limited phytoplankton biomass accumulation involved calculating the percentage of the response to light, N, P, or NP in comparison to the maximum response in all treatments for that water sample. In other words, the response metric used was based on the net change in fluorescence, not the percentage change in fluorescence relative to the control treatment. Light was assessed to limit net growth if the response in the control test tube was $50 \%$ of the highest response in any bioassay for that sample, regardless of how it responded in the $\mathrm{N}, \mathrm{P}$, or NP treatment. A nutrient was considered a 'limiting' nutrient if the net change in fluorescence increased by at least $75 \%$ of the highest response in any bioassay for that sample. Both N and P could limit phytoplankton growth if each, individually, had a net growth response that was $75 \%$ of the maximum observed for any sample. Less than $5 \%$ of all assays had no response, and were not included in this analysis. Some example calculations are given in Table 1.

We assessed the strength of the interaction of adding both $\mathrm{N}$ and $\mathrm{P}$ by 
calculating a response variable, the interaction effect index (IEI). The IEI is a measure of the synergy, or inhibition, between $\mathrm{N}$ and $\mathrm{P}$ additions in bioassays (Allgeier et al. 2011). The IEI is a relative measure of the response to multiple factors, and measures how much stronger, or weaker, the response is compared to the responses of individual additions added together. IEI $=\ln (\Delta \mathrm{NP} /(\Delta \mathrm{N}+\Delta \mathrm{P}))$, where $\Delta \mathrm{NP}, \Delta \mathrm{N}$, and $\Delta \mathrm{P}$ are net growth in fluorescence in the bioassay containers with the 3 different nutrient additions. IEI values close to 0 are additive because the response to $\mathrm{NP}$ is the sum of the response to the $\mathrm{N}$ addition and the $\mathrm{P}$ addition, but is not higher or lower. The IEI value increases above 0 when the interaction term becomes synergistic, and decreases if it is antagonistic (Allgeier et al. 2011).

We used the above criteria, to re-classify the results from 3 publications of similar bioassays for this shelf: Smith \& Hitchcock (1994), Sylvan et al. (2006), and Quigg et al. (2011). Their samples were collected in 4 different months (March, April, July, and September) in 4 years (1991, 1992, 2001, and 2004). The reported salinity range of samples collected by Quigg et al. (2011) was 27.8 to 29.0 (mean $\pm \mathrm{SD}, 28.7 \pm 0.34$ ), and 21.7 to $33.0(26.4 \pm 3.63)$ for all samples collected by Smith \& Hitchcock (1994). Salinity data were not reported by Sylvan et al. (2006), but the averages for the 3 mapped shelf and 4 plume survey areas ranged from 16.9 to $23.8(23.8,24.5,20.5,21.8,19.5,16.9$, and 23.3). There were 25 experiments from the 3 published studies, but only 14 with sufficient data to compare, and these are discussed in the 'Results'. The samples that we used in our re-analysis came from 3 months (March, July, and September) in 3 years. The criteria for re-assessment was that there was a figure or table with data that could be used to classify whether N, P, or NP was limiting net change in phytoplankton biomass, exclusive of nutrient ratios or other data, and that we applied the same $75 \%$ ( $\mathrm{N}$ and $\mathrm{P}$ ) and $50 \%$ (light) threshold used in our experiments.

\section{Water quality}

Each water sample was analyzed for chl a (using a fluorometric method with $90 \%$ acetone and $\mathrm{DMSO}$, and $\mathrm{HCl}$ acidification; Parsons et al. 1984), and dissolved nitrate, nitrite, (nitrate+nitrite), ammonium, and phosphate (Pi) (frozen samples analyzed in a Technicon autoanalyzer before 1990 and a Lachat autoanalyzer afterwards). The salinity data are from the shipboard CTD instrument attached to the Niskin rosette which gathered the sample water, or from commercially-available probes put in the surface water or collection bucket. DIN is the sum of inorganic nitrate, nitrite, and ammonia. The N:P ratio is the molar ratio of DIN:Pi.

\section{Definition of potential growth limitation}

The importance of nutrients in controlling primary production was examined by inferring the potential for nutrient limitation from nutrient ratios and concentrations. We adopted the following criteria given by Dortch \& Whitledge (1992): N limitation occurs when DIN $\leq 1 \mu \mathrm{M}, \mathrm{N}: \mathrm{P}<10$; P limitation occurs when $\mathrm{PO}_{4} \leq 0.2 \mu \mathrm{M}, \mathrm{N}: \mathrm{P}>30$.

\section{RESULTS}

\section{All samples}

The percentages of the bioassay results for all samples defined to be limited by light, NP, P, and N are plotted in Fig. 3. Three groupings are compared: all bioassay results with salinity data (30 bioassays had no salinity data), all bioassay results from 2010 and before, and all data for 2010. There was no obvious difference among the 3 data sets to suggest that the results of analyses by year or month depended on which of the 3 groupings was used. The commonalities among the 3 data sets are that the percentage of the total samples interpreted as lightlimited was between 15 and $27 \%$; 40 to $45 \%$ were NP-limited, $<10 \%$ were P-limited, and 20 to $38 \%$ were N-limited.

The results of the bioassays were used to summarize the N, P, NP, and light limitation. There were 5 times more N-limited samples than P-limited sam- 
ples for all data ( $\mathrm{n}=143)$, and 59 percent of the bioassays that were not light-limited were classified as being limited by NP. The response of the control flask, expressed as a percentage of the maximum net gain in fluorescence for all additions, was greatest at the lowest salinity, indicating the prevalence of light limitation below 20 (Fig. 4). The percentages of all bioassays that were defined as limited by light, NP, $\mathrm{P}$, or $\mathrm{N}$ for 4 salinity classes are shown in Fig. 5 ( $\mathrm{n}=$ 113). The light-limited bioassays declined from fresher to saltier waters from around 88 to $5 \%$, as the NP-limited samples rose from 5 to $60 \%$. The percentage of bioassays defined as P-limited remained low (at $10 \%$ or less), whereas the percentage defined as $\mathrm{N}$-limited rose from 5 to $30 \%$ in all samples.

\section{Comparisons by season and year}

The bimonthly changes in the percent of all samples defined as light- or nutrient-limited are shown in Fig. 6. The top panel is for the 2010 data, and the bottom panel represents all samples. Twenty percent of the 62 bioassays were defined as light-limited, and less than $15 \%$ of the bioassays were defined as Plimited. The ratio of $\mathrm{N}$ - to P-limited bioassays for all samples for April-May was 2:1 ( $\mathrm{n}=6), 9.5: 1$ in June-July $(\mathrm{n}=21), 4.5: 1$ in August-September $(\mathrm{n}=$ 11), and 2:1 in October-November $(\mathrm{n}=3)$. The average ratio for all data was 5:1.

The percent of bioassays defined as light-, N-, P-, or NP-limited for April $(n=35)$ and July $(n=45)$ in 3 different years is shown in Fig. 7. No bioassays were defined as P-limited in July or April, or in the 3 years

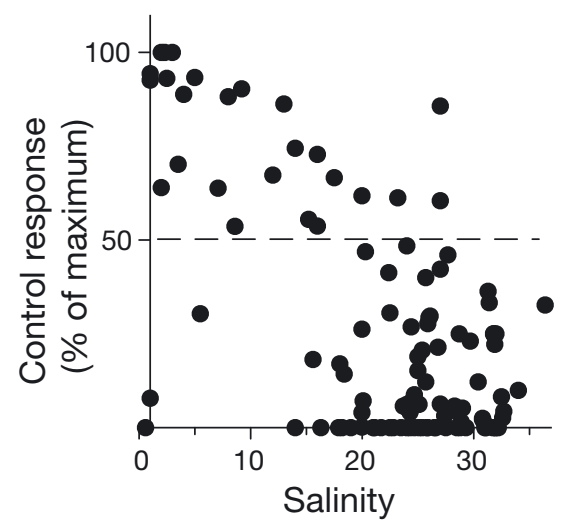

Fig. 4. Relationship between salinity ( $x$-axis) and the response in the control bioassay $(n=113)$, expressed as a percentage of the maximum response from all bioassay additions. Values above $50 \%$ of the maximum observed in the suite of bioassays from 1 location were defined as 'light-limited'
(1984, 1994, and 2010). There was a noticeable peak in the percentage of NP-limited bioassays in April 2010 and the absence of N- or P-limited samples in July 1994.

\section{Mississippi River water and Pi additions in 2011}

All of the bioassays conducted on the summer 2011 hypoxia cruise had Mississippi River water added in 1 part of the experiment and only Pi additions in a

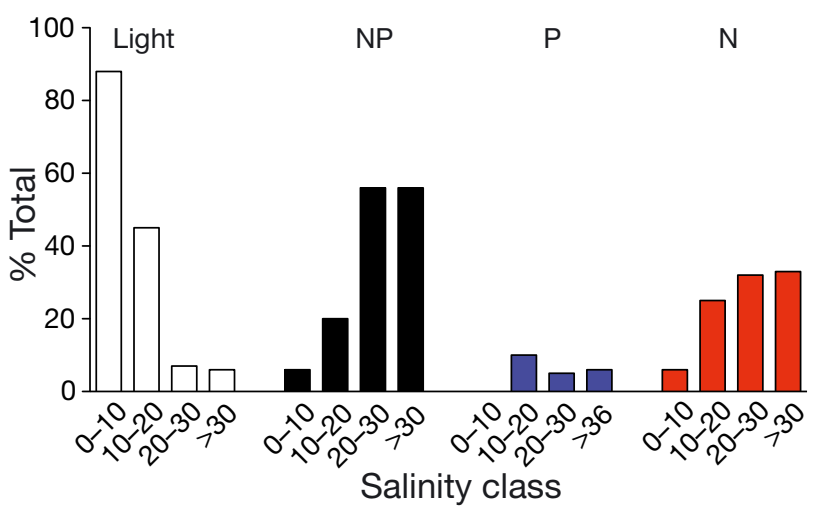

Fig. 5. Percent of all bioassays $(n=113)$ that were defined as limited by light, $\mathrm{N}$ plus $\mathrm{P}$ (NP), $\mathrm{P}$, or $\mathrm{N}$ in 4 salinity classes
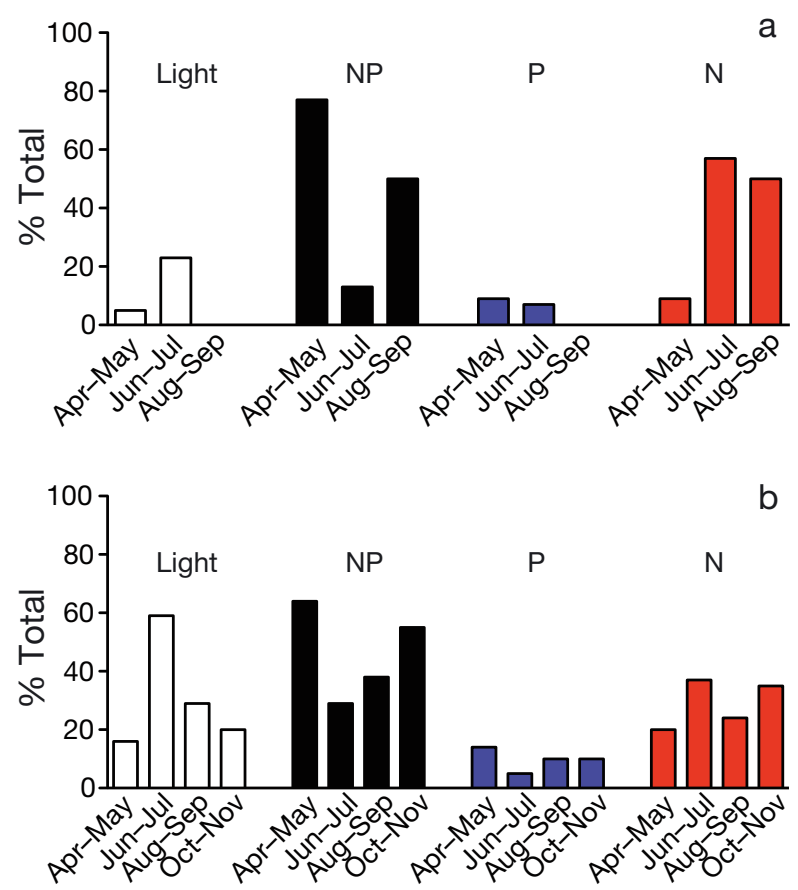

Fig. 6. Changes in the percent of all samples defined as light- or nutrient-limited for four 2 mo periods. (a) 2010 data $(\mathrm{n}=62)$, (b) all samples $(\mathrm{n}=143)$ 

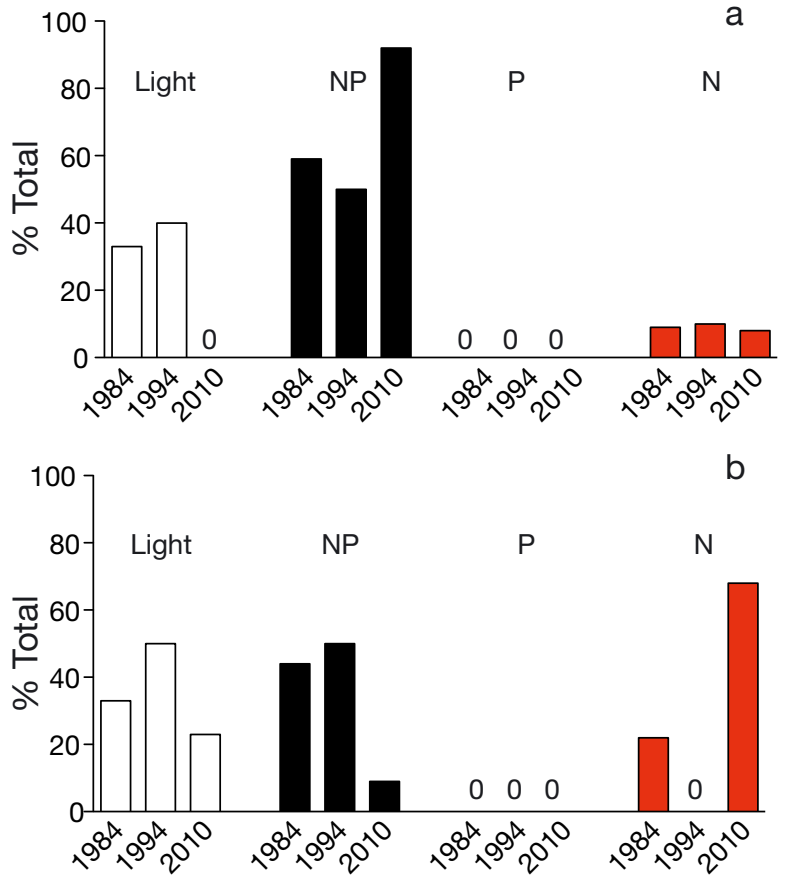

Fig. 7. Percent of bioassays defined as light-, $\mathrm{N}-_{-}, \mathrm{P}_{-}$, or $\mathrm{N}$ plus $\mathrm{P}(\mathrm{NP})$-limited for (a) April $(\mathrm{n}=35)$ and $(\mathrm{b})$ July $(\mathrm{n}=45)$ in 3 years $(1984,1994,2010)$

second part. The concentration of nitrate and phosphate in the water was 100.4 and $2.2 \mu \mathrm{M}$, respectively. No N additions were made in any 2011 experiment. No bioassay with only the Pi addition met the criteria for P limitation (i.e. when no river water was added). The average increase in fluorescence in the Pi-only additions that were not light-limited was $22.3 \pm 3.3 \%$ (mean $\pm 1 \mathrm{SE}$ ) of that in the bioassays with only river water added. This result is statistically indistinguishable from the changes in the bioassay control treatments that were interpreted not to be light-limited $(27.3 \pm 5.1 \%)$. The experiment was not set up to determine whether NP co-limitation occurred in these samples, but we can conclude from these experiments that $\mathrm{P}$ alone was not limiting phytoplankton growth on the shelf during the summer of 2011.

\section{Reclassification of three other studies}

Three publications of similar bioassays for this shelf were re-classified using the same criteria (see 'Materials and methods') to determine what nutrient was limiting. Quigg et al. (2011) reported that, using their criteria, there were 11 results, of which 1 was N-limited, 3 were P-limited, 4 were limited by multiple nutrients, and 3 were light-limited.
They provided 5 results in sufficient detail to re-classify them using our criteria, which were determined to be bioassays that included 1 that was P-limited, and 4 that were limited by a combination of $\mathrm{N}$ and $\mathrm{P}$. The results using our criteria agree with their results for the 5 experiments. Our re-analysis of 9 samples from Smith \& Hitchcock (1994) could be done on 5 of their experiments. This re-analysis yielded 1 sample with P limitation, 1 with $\mathrm{N}$ limitation, and 3 with NP limitation, which resulted in no conflicting results. Sylvan et al. (2006) had 4 samples that could be reclassified, yielding 2 experiments that were P-limited and 2 that were NP-limited. Again, there were no conflicting results. The total of the 3 studies was therefore $1 \mathrm{~N}$-limited bioassay, 4 P-limited bioassays, and 9 NP-limited bioassays.

\section{Nutrient concentrations}

The bioassay results were examined to determine whether there were any patterns related to nutrient concentrations and their ratios. The concentration of DIN and $\mathrm{Pi}$ in the sample water for each bioassay defined as N-, P-, or NP-limited is shown in Fig. 8. The concentration of DIN and Pi ranged 2 orders of magnitude among samples. Thirty-two of the 36 bioassays from this study that were defined as N-limited are within the red triangle of this figure that defines probable $\mathrm{N}$ limitation. Three of 7 bioassays

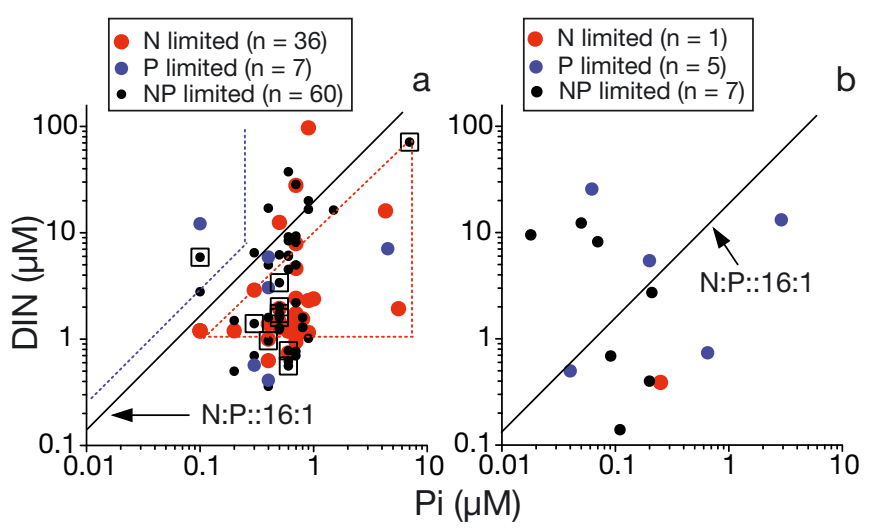

Fig. 8. Concentration of dissolved inorganic nitrogen and phosphorus (DIN and Pi) in the sample water for each bioassay defined as N-, P-, or N plus P (NP)-limited. (a) All samples from this study. (b) Samples from the literature with the identical criteria for defining limitation (redefined using data in the published paper). In panel a, 2 zones are identified: probable $\mathrm{N}$ limitation (red dotted line) and probable P limitation (to the left of the blue dotted line). These 2 zones were defined by Dortch \& Whitledge (1992). The black dots (NP-limited) with a square around them had an interaction effect index (IEI) value $>1$; note that all but 1 are below the area where $\mathrm{N}: \mathrm{Pi}<10$ 
defined as P-limited were also within this 'N-limited' triangle. Only 1 of 7 bioassays defined as P-limited was within the area described by Dortch \& Whitledge (1992) as likely to be P-limited. The bioassays defined as NP-limited were scattered in all areas of the plot, and $90 \%$ came from samples with an N:P ratio $<1: 16$. None of the bioassays defined as $\mathrm{N}$ limited was within the area of likely $\mathrm{P}$ limitation. There was no obvious separation into the 3 categories of nutrient limitation in the 14 examples from the literature. The NP-limited bioassays also had an IEI value $>1$, implying a synergistic interaction between the $\mathrm{N}$ and $\mathrm{P}$ additions to the bioassay. All but 1 are below the area where $\mathrm{N}: \mathrm{P}$ is $<10$. This result implies, but does not prove, that $\mathrm{N}$ is driving the $\mathrm{NP}$ interaction, not $\mathrm{P}$. If $\mathrm{P}$ were more important than $\mathrm{N}$, then one might expect a relatively sparse amount of Pi compared to $\mathrm{N}$ - i.e. a ratio much higher than the Redfield ratio of $16: 1$.

The general distribution of the data points is that they are below the line where the N:P ratio is $16: 1$. This may be an important point, because the DIN:P ratio in the river has been $\geq 16: 1$ for most months since the late 1970s (Turner et al. 2007), implying a greater retention of $\mathrm{P}$ compared to DIN as water is diluted with sea water. The dilution and uptake of DIN along the salinity gradient thus favors $\mathrm{Pi}$ retention over DIN in the surface layer.

\section{IEI}

The frequency distribution of IEI values for 3 different salinity zones is shown in Fig. 9. The results of a 1-way analysis of variance (ANOVA) of the data indicated that the 3 groups were distinct from each other $(F=3.26, \mathrm{p}=0.0425)$. A synergistic response to simultaneous $\mathrm{N}$ and $\mathrm{P}$ additions is indicated if the IEI values are $>0$. There is a change in the IEI values going from low- to high-salinity samples that indicates a variable response to $\mathrm{N}$ and $\mathrm{P}$ additions; the IEI values ranged between a slight antagonism to neutral interaction of $\mathrm{N}$ and $\mathrm{P}$ at low salinity $(<20)$, to a positive value for samples with a salinity between 20 and 30 (mean $=0.18)$, to a synergy at $>30$ (mean $=$ $0.27)$.

\section{DISCUSSION}

The 158 bioassays were collected in 8 different months and 10 different years, but not during winter months. The sampled waters extend twice the distance across the shelf of all previously reported bioassays and cover a much broader salinity range; ours are the only samples taken from west of Atchafalalya Bay. The salinity range of all 158 samples is from 0 to 36, whereas that of previous studies averaged between 17 and 29. These results expand the bioassay data available to assess nutrient limitation on this shelf (using the criteria we used) by an order of magnitude (158 versus 14 bioassays).

Our experiments were focused on the net growth of phytoplankton in $10 \mathrm{ml}$ test tubes, and the results were used to infer distinctions among nutrient limitation(s) of phytoplankton, but not food webs. The effects of the small bioassay tube does not seem to be a significant issue for the purpose of this analysis because the potential scaling issue has been examined by others without finding an effect of concern applicable to these experiments. The results of toxicity and growth studies using microplates $(100 \mu \mathrm{l})$, for example, are comparable to the results in 11 flasks (Blaise et al. 1986), and a comparison of nutrient enrichments in mesocosms ranging from 4 to 5000001 gave similar results (Spivak et al. 2011). We

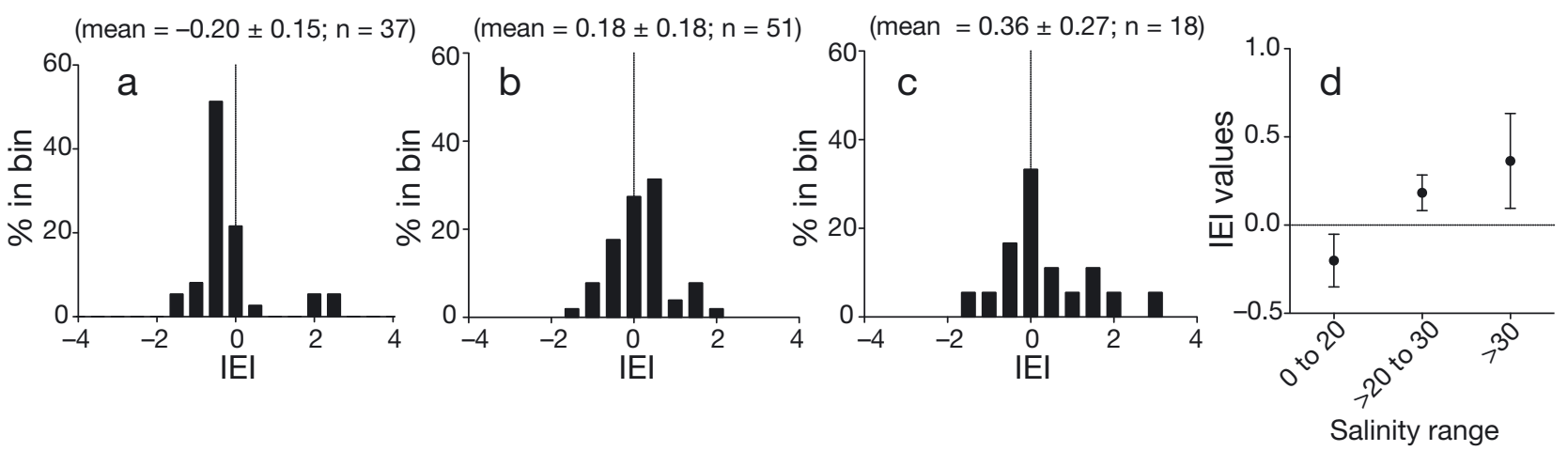

Fig. 9. Frequency distribution of the interaction effect index (IEI) values for different salinity zones: (a) salinity $0-20$, (b) $>20$ to 30, and (c) $>30$. Data in Panels a, b, and c are divided into 16 bins of 0.5 IEI units each. The mean \pm 1 SE is shown above the graph for each data set. (d) The 3 data sets are significantly different from each other (mean $\pm 1 \mathrm{SE} ; \mathrm{p}=0.043$ ) 
recognize that all bottle experiments have the potential to introduce artifacts that misrepresent natural systems. We are therefore hesitant to suggest that our $10 \mathrm{ml}$ test tube design should be used indiscriminately in food web analyses.

Three general patterns related to limitation along the salinity gradient emerge from these results: (1) light limitation occurs mainly where salinity is $<20$ (Fig. 4), (2) phytoplankton growth becomes mostly Nor NP-limited where salinity is $>20$ (Fig. 5), and (3) an $\mathrm{N}$ and $\mathrm{P}$ synergism exists most strongly where salinity is $>30$ (Fig. 9). Further, some general observations about the relative significance of N, P, and NP limitation are that (1) limitation of phytoplankton growth by $\mathrm{P}$ alone is not common (less than $10 \%$ of all samples), (2) there is no strong pattern of P limitation among years or months (Figs. 6 \& 7), and (3) there was no evidence of $\mathrm{P}$ limitation in the hypoxia cruises in 3 years using the standard bioassay, or in 2011 when using the modified bioassay (Mississippi River water addition plus Pi). Furthermore, $\mathrm{N}$ limitation occurred 5 times more often than did P limitation.

Several results indicate that the significant frequency of NP limitation in all samples (Fig. 4), and its dominance when salinity is $>20$ (Fig. 5), is strongly influenced more by $\mathrm{N}$ than $\mathrm{P}$ availability. First, the dilution of river water with sea water results, in general, in the NP-limited samples exhibiting a declining $\mathrm{N}: \mathrm{P}$ ratio as the concentration of DIN declines (Fig. 8). The concentration of Pi does not decline in proportion to the diminution in DIN concentration. This result suggests that $\mathrm{Pi}$ is conserved more efficiently than DIN along the dilution gradient. Second, most of the NP-limited samples are also located below the $\mathrm{N}: \mathrm{P}:: 16: 1$ line (Fig. 8). If $\mathrm{P}$ were more important than $\mathrm{N}$, then the anticipated result would be for the bioassays defined as P-limited to have N:P ratios $>16: 1$, but they do not. Third, only a few bioassays $(<10 \%)$ were defined as limited by P (Fig. 3).

This dichotomy of 2 competing nutrient limitation schemes, however useful as a diagnostic tool, does not fully represent the more complex situation as river water mixes with sea water. For example, IEI values showed a large range from 0 to 30 (Fig. 9), and NP co-limitation coincidental with positive IEI values (synergism) was common where the salinity was $>30$ (Fig. 9). All phytoplankton species and their communities will not exhibit homogeneous responses with respect to nutrient concentrations, although ecosystem models may treat them that way out of an expedient necessity arising, for example, from data limitations. Furthermore, different phytoplankton may have heterogeneous responses to the same concen- trations of DIN or Pi that are dependent on many other factors. In addition, the response to light was not linear across the range of salinities (Fig. 4). The national management goal of reducing $\mathrm{N}$ loading from the Mississippi River (SAB 2007) is predicated upon a causal relationship and direct coupling between $\mathrm{N}$ loading and hypoxic zone size in mid-summer. Thus, in spite of these uncertainties and variable responses, there exists an ability to predict the size of the hypoxic zone based on the nitrate-N loading 2 mo earlier (Turner et al. 2012); Justić et al. (1993) described lags between the nitrogen loading in the river and primary production (1 mo) and oxygen concentration $(2 \mathrm{mo})$ at one offshore station. The results from our experiments and these predictive capabilities support the string of logic statements linking nitrogen-N loading by the river, phytoplankton production, subsequent decomposition in bottom waters, and hypoxic water formation (Rabalais et al. 2010).

The inorganic N:P ratio may be used to screen samples for possible $\mathrm{N}$ or $\mathrm{P}$ limitation, but it was not a particularly accurate tool for that purpose when applied to the results from 158 bioassays we conducted and others in a fresher to more saline gradient (e.g. Ren et al. 2009). The presumed chemical boundaries describing likely areas of $\mathrm{N}$ limitation (Fig. 8) are where most of the N-limited bioassays were found in our study. There were also other areas where some, but not all, P- and NP-limited bioassays were located. These results are thus consistent with the general criticisms of Maestrini et al. $(1984 a, b)$ and the cautions of Hecky \& Kilham (1988) and Dodds $(2003,2006)$ concerning the usefulness of the chemical ratios to define nutrient limitation. Klapwijk et al. (1989) compared the results from addition experiments on natural populations of lake samples to an interpretation of the inorganic N:P ratio in the water. They found agreement between the 2 methods in only about one-third of the samples, and that $\mathrm{P}$ limitation was only evident when the inorganic N:P ratio was $>50$. It appears that inorganic concentrations or N:P ratios should not be used to make final determinations about $\mathrm{P}$ limitations where the inorganic N:P ratios (molar basis) are $<50$, for example. In other words, the concentration of dissolved inorganic $\mathrm{N}$ and $\mathrm{P}$ cannot be used to reliably describe or separate out whether samples are limited by $\mathrm{N}$, P, or NP in these bioassays.

A management goal that focuses on reducing one nutrient and neglects another is problematic for several reasons. From a practical point of view, it is difficult to manage one nutrient alone, and there are good reasons to simultaneously manage both $\mathrm{N}$ and 
P in aquatic systems (Lewis et al. 2011). The wellknown Law of the Minimum that Sprenger described for agricultural systems and that Liebig popularized (van der Ploeg et al. 1999) is a way of expressing how there are many factors affecting ecosystem behavior, because nutrient cycling is embedded in a constellation of interrelated factors. Reducing the molar ratio of silicate and nitrogen below 1:1, for example, can have consequences for the diatom-zooplankton-fish food webs on this coast and elsewhere (Turner et al. 1998). A policy of reducing $N$ (or P), but not $N$ and $P$, therefore may result in the creation of an unexpected or unique habitat space with consequences for water quality. Reducing only one nutrient, if implemented, could allow novel phytoplankton communities the luxury of another uninhabited niche space to exploit with unknown consequences. It behooves resource managers to favor an informed policy of multiple $\mathrm{N}$ and $\mathrm{P}$ reductions to reduce the size of the hypoxic zone on the northern Gulf of Mexico continental shelf. The cumulative effect of these results and uncertainties substantiate our previously stated recommendation, and those of others, to reduce both $\mathrm{N}$ and $\mathrm{P}$ in the watershed (Turner \& Rabalais 1991, Rabalais et al. 2002, Sylvan et al. 2006, SAB 2007, Lewis et al. 2011, Quigg et al. 2011). The SAB (2007), in particular, brought all the previous studies and those in the literature up to 2007 to bear in recommending that both the $\mathrm{N}$ and the $\mathrm{P}$ load should be reduced by $45 \%$ to meet the agreed upon management goal of reducing the average size of the hypoxic zone to $<5000 \mathrm{~km}^{2}$. We encourage the continued emphasis of $\mathrm{N}$ and $\mathrm{P}$ mitigation efforts in the Mississippi River watershed for improved water quality there, as well as in the northern Gulf of Mexico.

Acknowledgements. This analysis was supported by the National Oceanic and Atmospheric Administration, Center for Sponsored Coastal Ocean Research, under awards NA06OP0528 and NA09NOS4780204 to Louisiana Universities Marine Consortium and awards NA06OP0529 and NA09NOS4780230 to Louisiana State University. Funds for determining the size of the hypoxic zone since 1985 have come from the NOAA Coastal Ocean Program, National Ocean Service and Center for Sponsored Coastal Ocean Research, Louisiana Board of Regents, and the Louisiana Sea Grant Program. V. Abernethy, R. L. Allen, B. Cole, D. D. Dow, J. M. Lee, C. S. Milan, W. Morrison, T. A. Oswald, L. Pride, K. Reynolds, A. Sapp, L. Smith, E. M. Swenson, T. Widgeon, and many students assisted in the laboratory analyses and field work. We thank the crew of the RV 'Pelican' for the timely and persistent application of their logistical, technical, and culinary skills. The helpful comments of 2 anonymous reviewers are acknowledged. This is NOAA CSCOR NGOMEX Publication No. 171.

\section{LITERATURE CITED}

Allen EJ, Nelson EW (1910) On the artificial culture of marine plankton organisms. J Mar Biol Assoc UK 8:421-474

Allgeier JE, Rosemond AD, Layman CA (2011) The frequency and magnitude of non-additive responses to multiple nutrient enrichment. J Appl Ecol 48:96-101

Blaise C, Legault R, Bermingham N, Van Coillie R, Vasseur P (1986) A simple microplate algal assay technique for aquatic toxicity assessment. Toxicol Assess 1:261-281

Broussard W, Turner RE (2009) A century of changing land use and water quality relationships in the continental U.S. Front Ecol Environ 7:302-307

Caraco N, Tamse A, Boutros O, Valiela I (1987) Nutrient limitation of phytoplankton growth in brackish coastal ponds. Can J Fish Aquat Sci 44:473-476

D'Elia CJ, Sanders G, Boyton WR (1986) Nutrient enrichment studies in a coastal plain estuary: phytoplankton growth in large-scale, continuous cultures. Can J Fish Aquat Sci 43:397-406

Dodds WK (2003) Misuse of inorganic N and soluble reactive $\mathrm{P}$ concentrations to indicate nutrient status of surface waters. J N Am Benthol Soc 22:171-181

Dodds WK (2006) Nutrients and the 'dead zone': the link between nutrient ratios and dissolved oxygen in the northern Gulf of Mexico. Front Ecol Environ 4:211-217

$>$ Dortch Q, Whitledge TE (1992) Does nitrogen or silicon limit phytoplankton production in the Mississippi River plume and nearby regions? Cont Shelf Res 12:1293-1309

- Fisher TR, Gustafson AB, Sellner K, Lacunture R, Haas LW, Magnien R, Karrh MB (1999) Spatial and temporal variation in resource limitation in Chesapeake Bay. Mar Biol 133:763-778

Hecky RE, Kilham P (1988) Nutrient limitation of phytoplankton in freshwater and marine environments: a review of recent evidence on the effects of enrichment. Limnol Oceanogr 33:796-822

Justić D, Rabalais NN, Turner RE, Wiseman WJ Jr (1993) Seasonal coupling between riverborne nutrients, net productivity and hypoxia. Mar Pollut Bull 26:184-189

Klapwijk SP, Bolier G, van der Does J (1989) The application of algal growth potential tests (AGP) to the canals and lakes of western Netherlands. Hydrobiologia 188-189: 189-199

> Lewis WM Jr, Wurtsbaugh WA, Paerl HW (2011) Rationale for control of anthropogenic nitrogen and phosphorus to reduce eutrophication of inland waters. Environ Sci Technol 45:10300-10305

Lohrenz SE, Fahnenstiel GL, Redalje DG, Lang GA, Chen X, Dagg MJ (1997) Variations in primary production of northern Gulf of Mexico continental shelf waters linked to nutrient inputs from the Mississippi River. Mar Ecol Prog Ser 155:45-54

Lohrenz SE, Redalje DG, Cai WJ, Acker J, Dagg MJ (2008) A retrospective analysis of nutrients and phytoplankton productivity in the Mississippi River Plume. Cont Shelf Res 28:1466-1475

Maestrini SY, Bonin DJ, Droop MR (1984a) Phytoplankton as indicators of sea water quality: bioassay approaches and protocols. In: Shubert LE (ed) Algae as ecological indicators. Academic Press, New York, NY, p 71-132

Maestrini SY, Droop MR, Bonnin DJ (1984b) Test algae as indicators of sea water quality: prospects. In: Shubert LE (ed) Algae as ecological indicators. Academic Press, New York, NY, p 133-188 
Morel FMM (1987) Kinetics of nutrient uptake and growth in phytoplankton. J Phycol 23:137-150

Nixon SW, Pilson ME, Oviatt CA, Donaghay P and others (1984) Eutrophication of a coastal marine ecosystem - an experimental study using the MERL microcosms. In: Fasham MJR (ed) Flows of energy and materials in marine ecosystems. NATO Conf Ser 4, Mar Sci Vol 13. Plenum, New York, NY, p 105-135

Parsons TR, Maita Y, Lalli CM (1984) A manual of chemical and biological methods for seawater analysis. Pergamon Press, New York, NY

Quigg A, Sylvan JB, Gustafson AB, Fisher TR, Oliver RL, Tuzzi S, Ammerman JW (2011) Going west: nutrient limitation of primary production in the northern Gulf of Mexico and the importance of the Atchafalaya River. Aquat Geochem 17:519-544

Rabalais NN, Turner RE, Dortch Q, Justić D, Bierman VJ Jr, Wiseman WJ Jr (2002) Nutrient-enhanced productivity in the northern Gulf of Mexico: past, present and future. Hydrobiologia 475/476:39-63

Rabalais NN, Díaz RJ, Levin LA, Turner RE, Gilbert D, Zhang J (2010) Dynamics and distribution of natural and human-caused hypoxia. Biogeosciences 7:585-619

Ren L, Rabalais NN, Turner RE, Morrison W, Mendenhall W (2009) Nutrient limitation on phytoplankton growth in the upper Barataria Basin, Louisiana: microcosm bioassays. Estuar Coast 32:958-974

Science Advisory Board (SAB) (2007) Hypoxia in the northern Gulf of Mexico, an update. US Environmental Protection Agency, Science Advisory Board Hypoxia Advisory Panel, Report EPA-SAB-08-003. US Environmental Protection Agency, Washington, DC

Sen Gupta BK, Turner RE, Rabalais NN (1996) Seasonal oxygen depletion in continental-shelf waters of Louisiana: historical record of benthic foraminifers. Geology 24:227-230

Smith SM, Hitchcock GJ (1994) Nutrient enrichments and

Editorial responsibility: Patricia Glibert,

Cambridge, Maryland, USA phytoplankton growth in the surface waters of the Louisiana Bight. Estuaries 17:740-753

Spivak AC, Vanni MJ, Mette EM (2011) Moving on up: Can results from simple aquatic mesocosm experiments be applied across broad spatial scales? Freshw Biol 56: 279-291

Sylvan JB, Dortch Q, Nelson DM, Maier Brown AF, Morrison W, Ammerman JW (2006) Phosphorus limits phytoplankton growth on the Louisiana shelf during the period of hypoxia formation. Environ Sci Technol 40:7548-7553

Turner RE, Rabalais NN (1991) Changes in the Mississippi River this century: implications for coastal food webs. BioScience 41:140-147

Turner RE, Rabalais NN (1994) Coastal eutrophication near the Mississippi River delta. Nature 368:619-621

Turner RE, Qureshi N, Rabalais NN, Dortch Q, Justić D, Shaw R, Cope J (1998) Fluctuating silicate:nitrate ratios and coastal plankton food webs. Proc Natl Acad Sci USA 95:13048-13051

Turner RE, Rabalais NN, Alexander RB, McIsaac G, Howarth RW (2007) Characterization of nutrient and organic carbon and sediment loads and concentrations from the Mississippi River into the northern Gulf of Mexico. Estuar Coast 30:773-790

Turner RE, Rabalais NN, Justić D (2008) Gulf of Mexico hypoxia: alternate states and a legacy. Environ Sci Technol 42:2323-2327

Turner RE, Rabalais NN, Justić D (2012) Predicting summer hypoxia in the northern Gulf of Mexico: redux. Mar Pollut Bull 64:319-324

van der Ploeg RR, Böhm W, Kirkham MB (1999) On the origin of the theory of mineral nutrition of plants and the Law of the Minimum. Soil Sci Soc Am J 63:1055-1062

Walker NN, Rabalais NN (2006) Relationships among satellite chlorophyll $a$, river inputs, and hypoxia on the Louisiana continental shelf, Gulf of Mexico. Estuar Coast 29:1081-1093

Submitted: March 13, 2012; Accepted: November 7, 2012 Proofs received from author(s): February 4, 2013 